\title{
MOOD ECOLOGY AKTIVATOR UNTUK SETIAP TEMPAT
}

\author{
Giovani Baptista $^{1)}$, Maria Veronica Gandha ${ }^{2)}$ \\ 1)Program Studi S1 Arsitektur, Fakultas Teknik, Universitas Tarumanagara, giovanibaptista7@gmail.com \\ 2) Program Studi S1 Arsitektur, Fakultas Teknik, Universitas Tarumanagara, Alamat email
}

\begin{abstract}
Abstrak
Seiring perkembangan zaman, populasi manusia dan tuntutan zaman pun terus berkembang sehingga manusia harus menyesuaikan diri untuk dapat bertahan hidup. Dalam kehidupannya manusia menghadapi banyak rintangan yang mempengaruhi kondisi dari mental dan kinerja mereka. Ketika manusia berada dalam suasana hati yang senang, maka derajat kualitas hidup manusia pun meningkat, begitu pun sebaliknya. Namun, kehidupan di perkotaan yang serba cepat dan padat ini, membuat mereka sulit untuk melepaskan perasaan stres mereka akibat masalah yang dihadapi setiap harinya, ruangan sebagai tempat pelepas stres yang ada di perkotaan tidak cukup untuk menangani stres di perkotaan yang padat ini. Perancangan sebuah ruang sebagai aktivator bagi suasana hati manusia ini dirancang untuk menjangkau titik - titik yang ada di perkotaan, supaya dapat membantu melepaskan stres mereka. Tempat yang membantu aktivitas masyarakat dan membantu melepaskan stres yang mereka hadapi. Perkotaan yang padat, membuat manusia harus dapat memanfaatkan ruangan dengan baik. Oleh karena itu ruang aktivator ini dirancang agar memiliki luasan berskala kecil. Proyek ini dimulai dari menentukan program dan tujuan utama, program utama akan diajukan pada setiap titik pengembangan proyek, namun program ini akan tetap dikaji kembali kecocokannya dengan tapak yang akan diambil. Lalu diambil sampel lokasi, yaitu Kelurahan Pasar Baru sebagai lokasi penelitian sebelum proyek ini disebar ke berbagai titik di perkotaan. Ditemukan 3 titik lokasi pada Kelurahan Pasar Baru, karena perbedaan fungsi dan kecocokan program utama dengan fungsi program yang akan dirujuk pada tapak tersebut. Hasil sampel ini kemudian akan menjadi acuan bagi pengembangan proyek di titik lokasi yang berbeda kedepannya.
\end{abstract}

Kata kunci: Aktivator; Ruang; Suasana hati; Stres.

\begin{abstract}
Along with the times, the human population and the demands of the times continue to grow, so humans must adapt to survive. In life, humans face many obstacles that affect their mental condition and performance. When humans are in a happy mood, the degree of quality of human life increases, and vice versa. However, life in this fast-paced and dense urban area makes it difficult for them to release their stressful feelings due to the problems they face every day, the space as a stress-relief place in urban areas is not enough to handle stress in this crowded city. The design of a space as an activator for human mood is designed to reach points in urban areas, in order to help release their stress. A place that helps people's activities and helps release the stress they face. Dense cities, make people have to be able to make good use of space. Therefore, this activator chamber is designed to have a small-scale area. This project starts from determining the main program and objectives, the main program will be proposed at each point of project development, but this program will still be reviewed for suitability with the site to be taken. Then a sample location was taken,
\end{abstract}


namely Pasar Baru Village as a research location before this project was spread to various points in urban areas. Three locations were found in Pasar Baru Village, due to differences in the function and compatibility of the main program with the function of the program to be referred to at that site. The results of this sample will then be used as a reference for project development at different location points in the future.

Keywords: Activator; Mood; Room; Stress.

\section{PENDAhUluAN}

\section{Latar Belakang}

Semakin berkembangnya zaman, perkotaan di Jakarta juga berkembang semakin padat, perkembangan ini yang padat ini diiringi dengan pertambahan bangunan yang semakin menyesakkan kehidupan perkotaan, stress yang terjadi di perkotaan pun semakin meningkat karena beberapa faktor, seperti kurangnya ruang terbuka hijau, kesenjangan ekonomi, fasilitas umum yang kurang memadai, mahalnya tempat tinggal, dan lain-lain. Lantas bagaimana kehidupan perkotaan di masa yang akan datang? Apakah masyarakat perkotaan akan semakin stres seiring perkembangan zaman? Terdapat data bahwa dalam rentang waktu lima tahun terakhir terjadi peningkatan stres berupa gangguan mental emosional.

Penderita gangguan jiwa di Jakarta cenderung meningkat dalam rentang waktu lima tahun terakhir. Prevalensi gangguan mental emosional di DKI Jakarta tahun 2018 sebesar 10,1 persen, lebih tinggi dari rata-rata tingkat nasional (9,8 persen). Penderita gangguan ini lebih banyak dialami perempuan daripada laki-laki. Jenis gangguan jiwa yang paling banyak mereka derita ialah gangguan kecemasan dan depresi. Meningkatnya penderita gangguan jiwa tersebut tidak terlepas dari adanya tekanan hidup di perkotaan seperti tekanan ekonomi, perubahan sosial yang cepat, dan polusi udara. ${ }^{1}$

\footnotetext{
${ }^{1}$ Artikel ditulis oleh Antonius Purwanto, www.kompas.com, 2019
} 


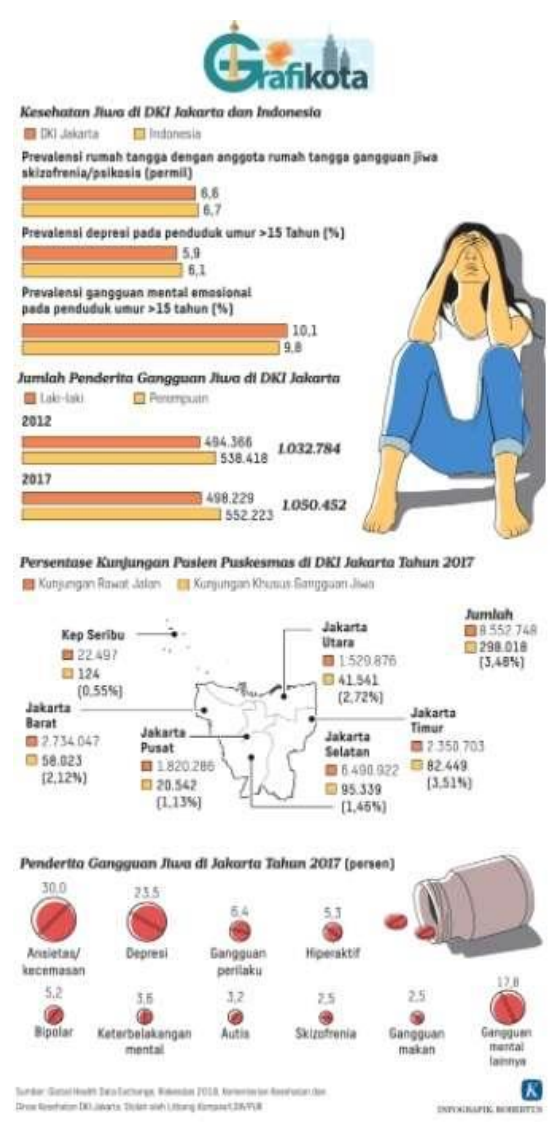

Gambar 1: Grafik Stress

Sumber: kompas.id 2019

\section{Rumusan Masalah}

Stres yang terjadi pada masyarakat di perkotaan yang semakin menigkat seiring perkembangan zaman menjadi pertanyaan akan bagaimana kehidupan masyarakat perkotaan di masa yang akan datang, sehingga harus dibuat suatu gerakan atau suatu proyek yang membantu memastikan kehidupan masyarakat perkotaan di masa yang akan datang memiliki derajat kualitas hidup yang baik.

\section{Tujuan}

Studi ini bertujuan untuk memberikan usulan atas rumusan masalah, yaitu sebagai ruangan aktivator yang dapat membantu masyarakat disekitarnya mendapatkan derajat kualitas hidup yang baik melalui emosi/perasaan yang baik atau positif, dibutuhkan juga media pendidikan masyarakat akan pentingnya mengenal dan menjaga lingkungan, tempat ini dapat menjadi tempat rekreasi jarak dekat untuk masyarakat perkotaan maupun luar kota, tempat yang memenuhi kebutuhan manusia akan ruang di sekitarnya, tempat ini juga dapat diusulkan juga sebagai tempat survey kegiatan masyarakat dan sebuah layer digital yang baru dalam mengenal suatu daerah. Sehingga dapat membantu derajat kualitas kehidupan masyarakat perkotaan di masa yang akan datang.

\section{KAJIAN LITERATUR}

\section{Definisi Emosi}

Hidup manusia dipengaruhi oleh suasana hati dan suasana hati dipengaruhi oleh emosi yang mereka rasakan setiap harinya. Emosi manusia dipengaruhi oleh banyak aspek, salah satunya adalah aspek lingkungan. Emosi pada manusia akan mempengaruhi pola pikir dan akhirnya apa yang mereka lakukan 
akan terpengaruh oleh perasaan itu sendiri. Emosi didefinisikan sebagai episode yang saling terkait, perubahan yang disinkronkan dalam keadaan semua atau sebagian besar dari lima subsistem organisme sebagai tanggapan terhadap evaluasi peristiwa stimulus eksternal atau internal yang relevan dengan perhatian utama organisme" (Pekrun \& Linnenbrink-Garcia, 2014).

Stres, kecemasan, depresi, dan kesepian, telah dikaitkan dengan hal-hal seperti penurunan kekebalan, peningkatan peradangan, dan penurunan harapan hidup.(Wolkowitz, 2010). Kebahagiaan telah dikaitkan dengan berbagai hasil termasuk peningkatan umur panjang dan peningkatan kepuasan pernikahan. Sebaliknya, ketidakbahagiaan telah dikaitkan dengan berbagai hasil kesehatan yang buruk. (Lawrence, 2015)..Emosi dapat memicu ingatan, dan sebaliknya. Sinkronisasi antara aktivitas di amigdala dan hipokampus bisa berjalan baik. Emosi meningkatkan ingatan, tetapi pada saat yang sama dengan mengingat peristiwa itu, Anda juga akan mengingat respon emosionalnya. Ini bisa seperti lingkaran di mana amigdala berinteraksi dengan hipokampus. " Menurut Dolcos, lingkaran ingatan ini bisa membantu memahami ingatan yang membakar dari ingatan traumatis pada orang dengan gangguan stres pascatrauma. (Duke University, 2005).

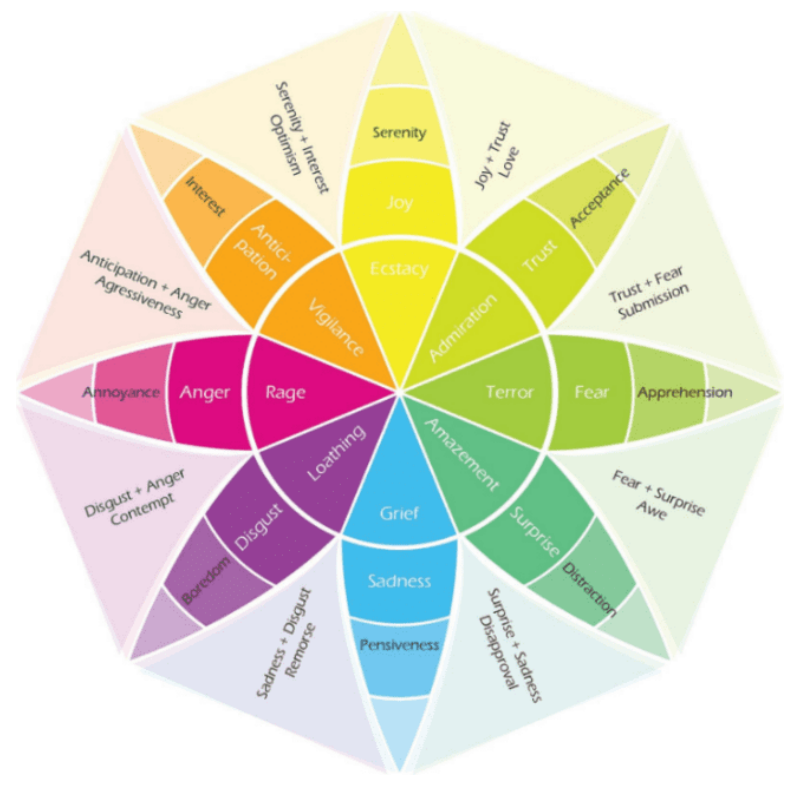

Gambar 2: Wheel of Emotion (Robert Plutchik)

Sumber: https://positivepsychology.com/emotion-wheel/

Emosi yang ada pada manusia sangat banyak dan ini adalah 8 emosi utama manusia. Emosi ini dibagi menjadi banyak tingkatan emosi dan gabungan antar emosi yang membentuk mood manusia.

\section{Cara meningkatkan hormon yang mempengaruhi emosi manusia}

- Dopamine (Erica Julson, MS, RDN, CLT 2018)

1. Mendapatkan cahaya matahari yang cukup

2. Sering berolahraga

3. Bermeditasi

- Serotonin (Crystal Raypole 2019)

1. Mendapatkan cahaya matahari yang cukup 
2. Sering berolahraga

3. Dekat dengan oranglain

- Oxytocin (Crystal Raypole 2020)

1. Mendengarkan musik

2. Berinteraksi dengan oranglain

3. Bermeditasi

- Endorphins (Crystal Raypole 2019)

1. Mendapatkan matahari yang cukup

2. Mendengarkan musik

3. Meditasi

4. Tertawa bersama teman atau oranglain

5. Sering berolahraga

6. Mencium bau alami atau bau alam

\section{Bentuk Ruang Publik}

Secara umum, ruang publik merupakan ruang terbuka yang mampu mengakomodasi kebutuhan akan tempat pertemuan dan kegiatan bersama di alam terbuka. Ruang ini memungkinkan pertemuan manusia untuk berinteraksi satu sama lain. Karena di ruang ini sering muncul berbagai kegiatan bersama, maka ruang terbuka ini dikategorikan sebagai ruang bersama.

Meskipun beberapa ahli mengatakan bahwa umumnya ruang publik adalah ruang terbuka. Berdasarkan Secara alami, ruang publik dibagi menjadi 2 jenis, yaitu: 1) Ruang publik tertutup: adalah ruang publik yang terdapat dalam suatu bangunan. 2) Ruang publik terbuka: yaitu ruang publik di luar gedung yang sering disebut ruang terbuka. Jenis - jenis ruang, 1) Ruang Privat, tempat yang tidak dapat dimasuki semua orang, digunakan untuk menikmati waktu sendiri dari setiap individu, ruangan ini dibutuhkan karena manusia membutuhkan tempat untuk sendirian, merenung, menangis, dan menenangkan dirinya, serta berpikir, atau bekerja. 2) Ruang Kerja, tempat untuk bekerja dan produktif. 3) Third Place, Tempat ketiga adalah lingkungan sosial yang terpisah dari dua lingkungan sosial biasa di rumah ("tempat pertama") dan tempat kerja ("tempat kedua"). Contoh tempat ketiga adalah lingkungan seperti gereja, kafe, klub, perpustakaan umum, toko buku atau taman. Dalam bukunya yang berpengaruh The Great Good Place (1989), Ray Oldenburg berpendapat bahwa tempat ketiga penting bagi masyarakat sipil, demokrasi, keterlibatan sipil, dan membangun perasaan tempat . Bentuk ruang publik beserta jenis ruang ini nantinya akan diaplikasikan terhadap bentuk dan penataan ruang, sehingga tercipta ruangan aktivator yang dapat digunakan bukan hanya oleh kalangan tertentu, namun oleh semua masyarakat umum.

\section{METODE PERANCANGAN}

Metode perancangan yang digunakan adalah 1) Menentukan program utama. 2) Menentukan kriteria tapak. 3) Melakukan survey tapak untuk membentuk program pada tapak. 4) Menggabungkan antara program utama dan program yang sesuai pada tapak, agar terjadi kesesuaian program yang akan dibangun pada tapak. 5) Menonjolkan atau membentuk kearifan lokal sesuai dengan tapak. 
Metode pengumpulan data ini menggunakan survey online, seperti mengambil luasan dari google maps, mengambil atau melihat kondisi dari google street view, mengumpulkan data transportasi dari google maps, mengumpulkan data kebiasaan masyarakat dari artikel di google.

Pengumpulan data ini kemudian dimasukkan kedalam analisis pattern language untuk melihat bagaimana kebiasaan atau bahasa desain dari lokasi tapak yang telah ditentukan, sehingga dapat dikeluarkan bentuk yang sesuai dengan lokasi tersebut, sehingga dapat menjadi bangunan yang hanya ada pada lokasi tapak tersebut dan menciptakan perbedaan pada lokasi - lokasi lainnya. Setelah datadata dikumpulkan, dilakukan proses analisis berupa pemisahan dan penyesuaian data yang akan digunakan sebagai acuan dalam merancang. Setelah analisis selesai, kemudian dikeluarkan sintesis yang menghasilkan kesimpulan bahwa, proyek Mood Ecology ini mengambil sebuah Kelurahan, yaitu Kelurahan Pasar Baru sebagai tempat sampel dari penelitian, karena lokasinya yang sesuai dengan kriteria pemilihan lokasi, ditemukan 3 titik lokasi yang memiliki perbedaan kegiatan pada Kelurahan ini, yaitu : 1) Sebagai lokasi perbelanjaan. 2) Sebagai lokasi tempat tinggal. 3) Sebagai lokasi kantor / tempat bekerja. Sehingga 3 titik lokasi yang berbeda ini dijadikan sampel pembentukan program yang nantinya akan diaplikasikan sebagai kriteria dari proyek ini ketika akan disebar ke daerah/lokasi lain.

Metode perancangan ini dimulai dari menentukan program dan tujuan utama sebagai garis acuan dalam mengembangkan proyek, pada diagram gambar 3 terdapat program utama yang akan diajukan pada setiap titik pengembangan proyek, namun program ini akan tetap dikaji kembali kecocokannya dengan tapak yang akan diambil. Lalu diambil sampel lokasi Kelurahan Pasar Baru sebagai lokasi penelitian sebelum proyek ini disebar ke berbagai titik perkotaan di Jakarta. Ditemukan 3 titik lokasi pada Kelurahan Pasar Baru, karena perbedaan fungsi dan kecocokan program utama dengan fungsi program yang akan dirujuk pada tapak tersebut. Hasil sampel ini kemudian akan menjadi acuan bagi pengembangan proyek di titik lokasi yang berbeda kedepannya.

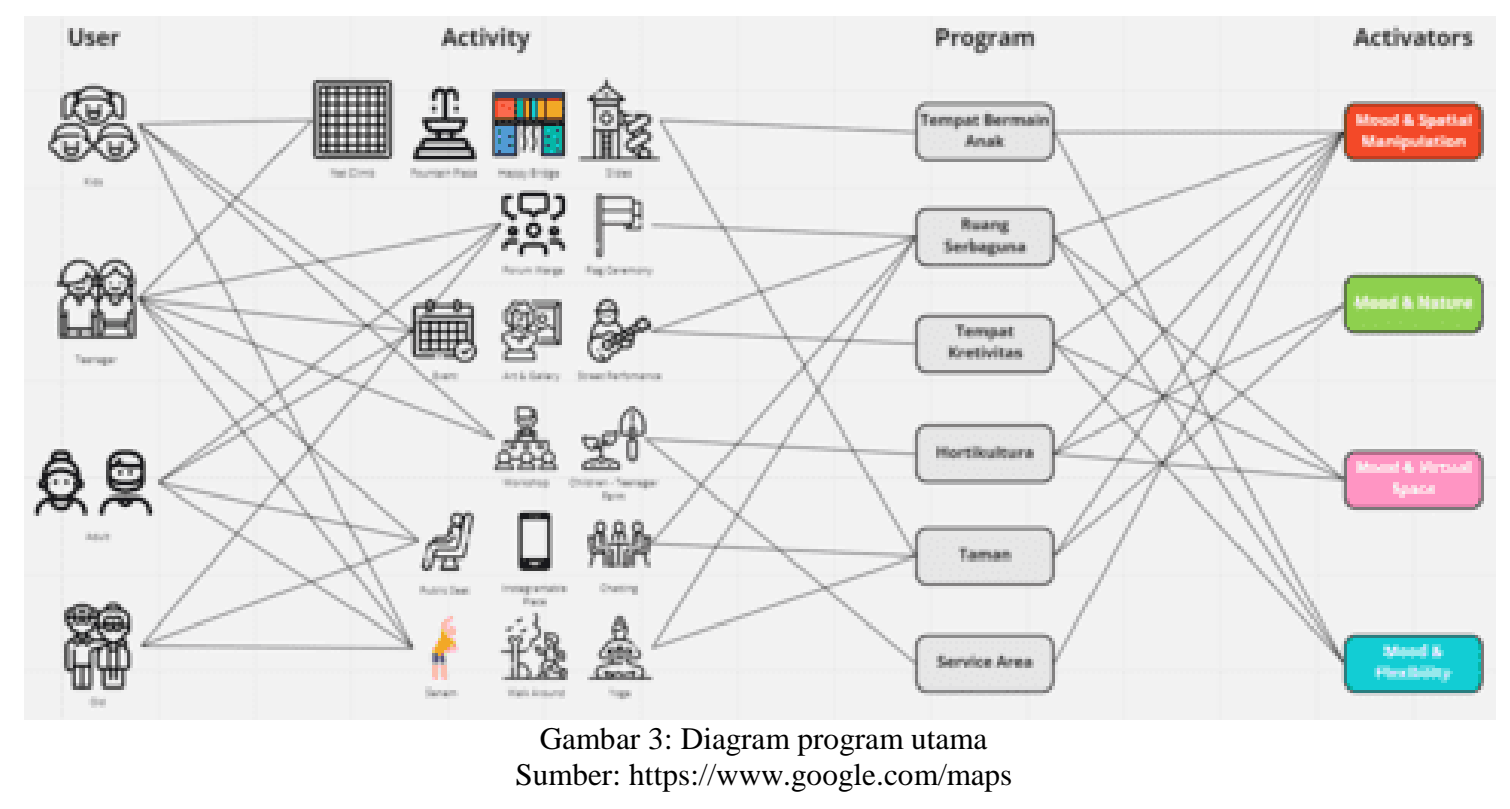

\section{Kriteria Pemilihan Tapak :}

1. Terletak pada kawasan yang memiliki kepadatan yang tinggi karena, kerumunan dapat memiliki efek merusak pada kesehatan mental dan dapat mengakibatkan kinerja yang buruk dari tugastugas kompleks, efek samping stres, dan peningkatan stres fisiologis. (https://dictionary.apa.org/crowding).

2. Memiliki keragaman fungsi peruntukkan bermacam - macam fungsi peruntukkan menyebabkan 
keragaman aktivitas masyarakat sehingga terjadi perbedaan keluaran ruang proyek.

3. Sedikit ruang terbuka hijau / RPTRA warga kota yang makin teralienasi (asing) satu sama lain, ikatan atau kohesi sosialnya mengendor, lalu meningkatkan gejala depresi baik yang ringan maupun berat. (https://tirto.id/kesehatan-jiwa-warga-kota-tergantung-kondisi-ruang-publiknyactcy).

4. Bangunan tidak layak / ditinggalkan / lahan kosong sebagai tempat proyek akan dibangun.

5. Perbedaan tingkat ekonomi perbedaan tingkat perekenomian menyebabkan keragaman yang kompleks dan perbedaan komunitas.

\section{DISKUSI DAN HASIL}

\section{Pemilihan lokasi}

Lokasi proyek terletak pada Kelurahan Pasar Baru, Jakarta Pusat. Kelurahan Pasar Baru ini dikenal sebagai salah satu kawasan perbelanjaan tertua di Jakarta, namun Kelurahan Pasar Baru ini ternyata juga dikelilingi berbagai landmark seperti, Gereja Kathedral, Masjid Istiqlal, Gereja Ayam, Kantor Pos, menjadikannya sebagai lokasi yang menarik. Kelurahan Pasar Baru juga terbagi menjadi beberapa area dengan fungsi berbeda, yaitu : area perbelanjaan, area tempat tinggal, dan area perkantoran.

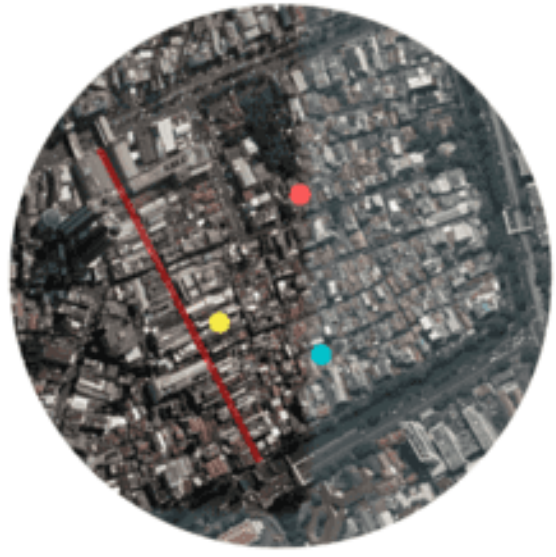

Gambar 4: Titik lokasi pemilihan tapak Sumber: https://www.google.com/maps

Tapak yang diambil berada pada titik di gambar 4, yaitu: 1) Jl. Pasar Baru 1, Sawah Besar, Jakarta Pusat. 2) Jl. Kelinci 2, Sawah Besar, Jakarta Pusat. 3) Jl. Kelinci Raya, Sawah Besar, Jakarta Pusat.

Tapak 1 dengan warna titik kuning berfungsi sebagai passage bagi Jalan Pasar Baru dan Jalan Belakang Pasar Baru yang merupakan Kawasan perbelanjaan. Total area : $1008 \mathrm{~m}^{2}$, zonasi : perkantoran, perdagangan, jasa, KDB : 75, KLB : 3, KB : 4, KDH : 30, KTB : 55. 


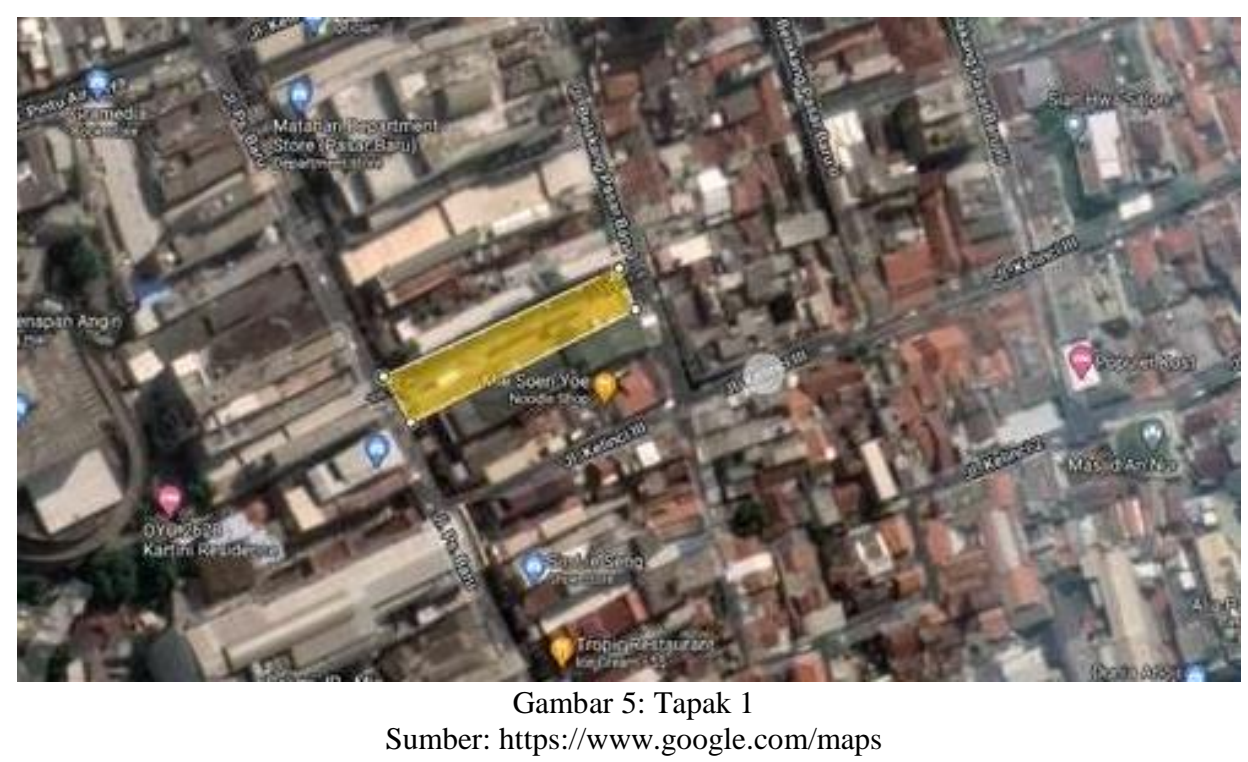

Tapak 2 dengan warna cyan berfungsi sebagai tempat untuk menampung kebutuhan ruang area tempat tinggal untuk beraktivitas. Total area : $342 \mathrm{~m}^{2}$, zonasi : perkantoran, perdagangan, jasa, KDB : 75, KLB : 3, KB : 4, KDH : 30, KTB : 55.

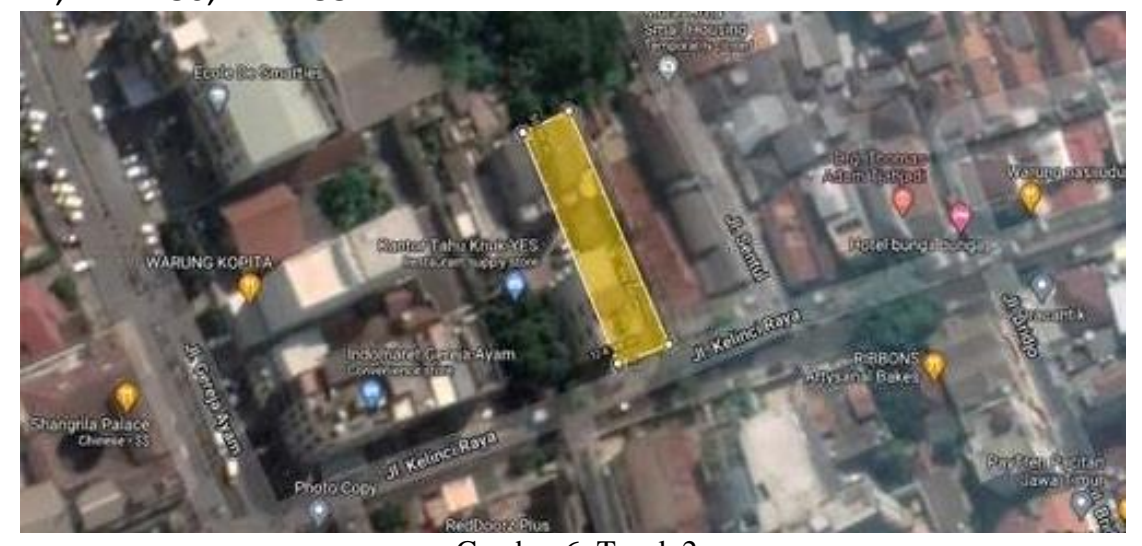

Gambar 6: Tapak 2

Sumber: https://www.google.com/maps

Tapak 3 dengan warna merah berfungsi sebagai tempat yang membantu daerah perkantoran dan para pengusaha baru / start up merintis karirnya, sebuah tempat yang menyediakan kebutuhan pekerja kantor akan ruang bekerja, meeting, berbincang, beristirahat, dan berolahraga. Total area : $557 \mathrm{~m}^{2}$, zonasi : Campuran, KDB : 60, KLB : 2.4, KB : 4, KDH : 30, KTB : 55.

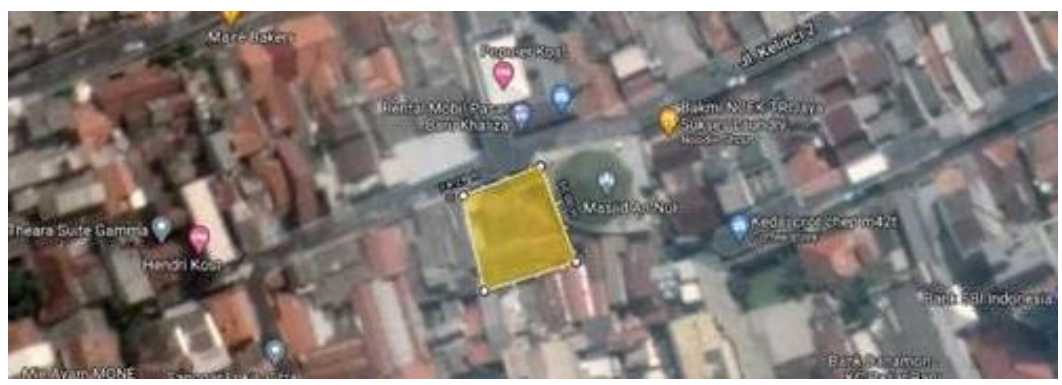

Gambar 7: Tapak 3

Sumber: https://www.google.com/maps 


\section{Konsep}

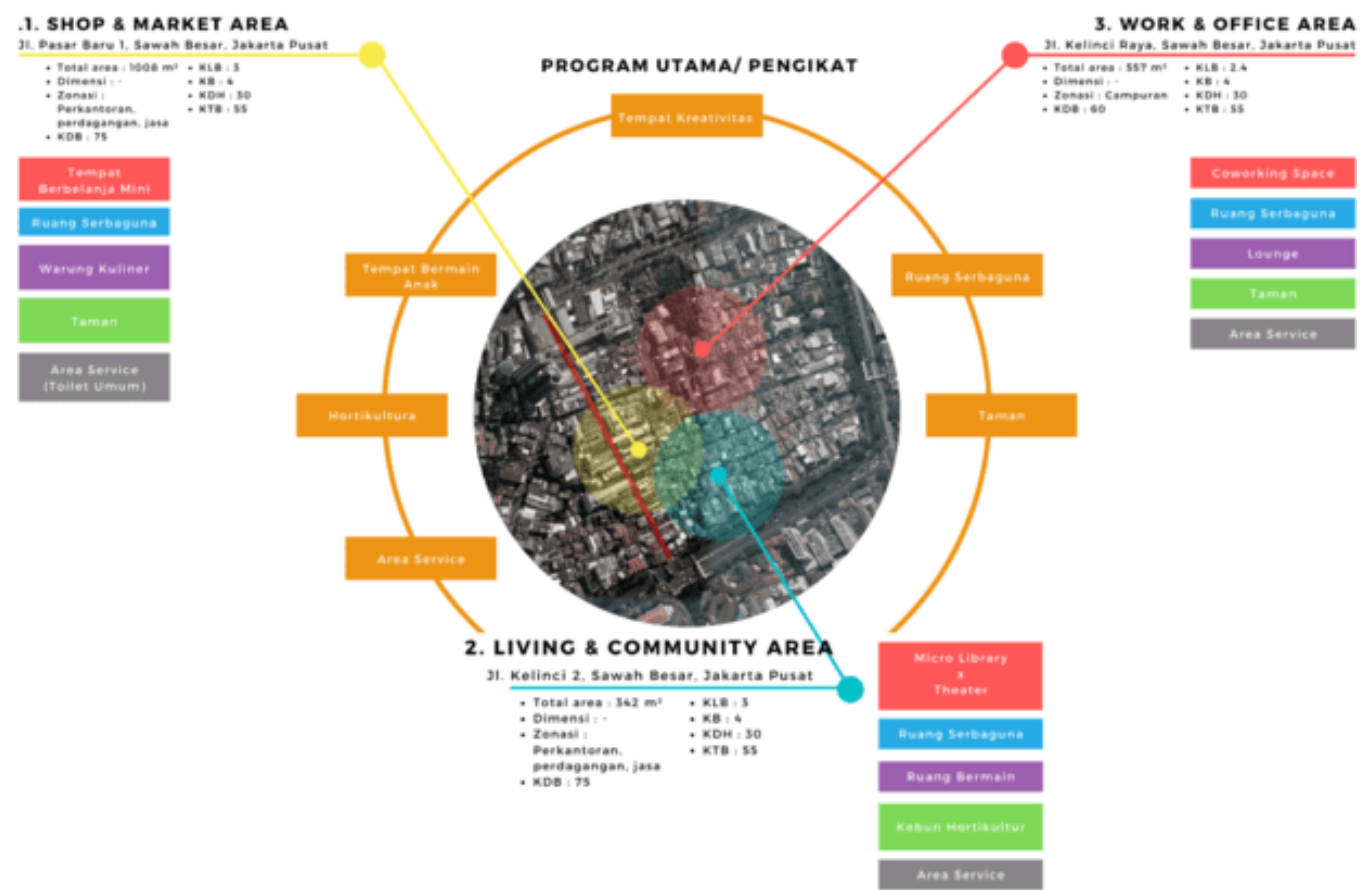

Gambar 8: Program dan tapak Sumber:

\section{Tapak 1 (JI. Pasar Baru 1, Sawah Besar, Jakarta Pusat)}

Tapak ini menjadi passage bagi Jalan Pasar Baru \& Jalan Belakang Pasar Baru, tapak ini dikembangkan sebagai shop \& market area dengan konsep mikro retail berukuran $3.5 \mathrm{~m} \times 3.5 \mathrm{~m}$. Tapak ini memiliki program berupa mikro retail yaitu toko berbelanja mini, café, urban plant, dan passage yang dilengkapi dengan area taman serta warung kuliner, dimana pengunjung dapat melewati jalan sambil merasakan suasana taman juga berwisata kuliner.

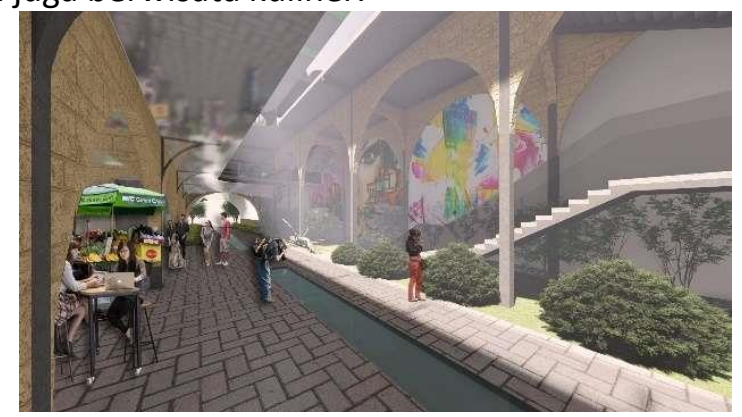

Gambar 9: Passage

Sumber:

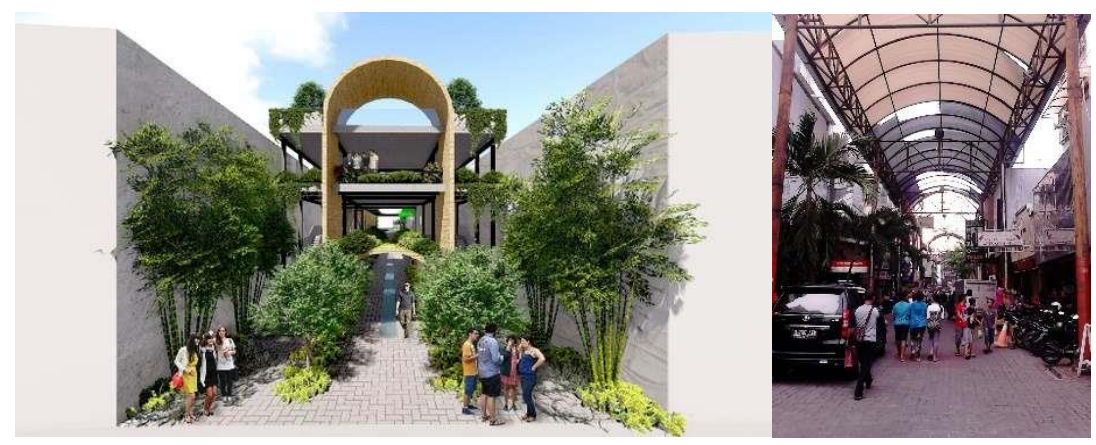

Gambar 10: Tampak depan \& Bentuk kanopi Pasar Baru Sumber: https://thetravelearn.com 
Bagian gate dari bangunan ini mengambil bentuk dari kanopi Jalan Pasar Baru, agar tercipta perasaan bahwa mereka masi berada dalam kawasan yang sama, namun ditambahkan vegetasi untuk membantu pengunjung mendapatkan suasana lebih tenang dan segar.

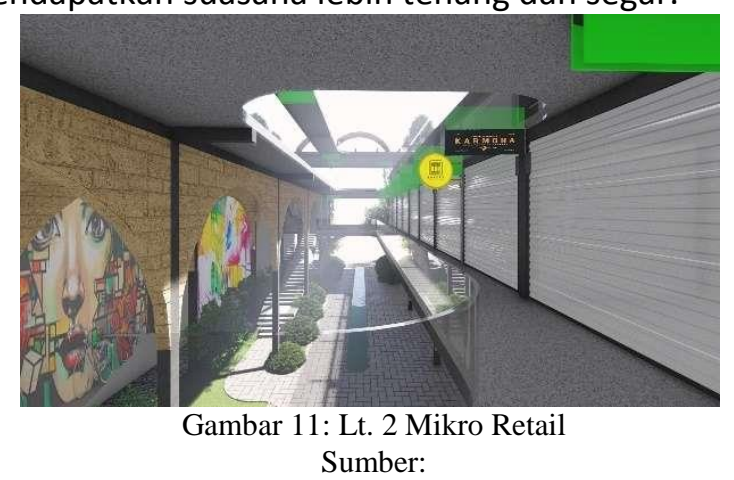

Bentuk depan retail menggunakan rolling door untuk keamanannya, karena ketika retail dibuka, maka rolling door ini akan dibuka juga dan membuka seluruh bagian toko, sehingga tidak mengurangi luasan dari toko yang sudah berukuran kecil ini, juga mengambil dari bentuk toko-toko di Pasar Baru yang menggunakan pintu dengan keamanan yang serupa.

Pada gambar 11 dapat dilihat bahwa void dibuat mengikuti cahaya matahari pagi dari arah Timur, untuk memasukkan pencahayaan alami matahari ke dalam tapak sampai lantai dasar, sehingga mendapat pencahayaan dan juga perasaan lebih leluasa dalam bangunan ini, juga untuk menghidupkan vegetasi pada setiap lantai.

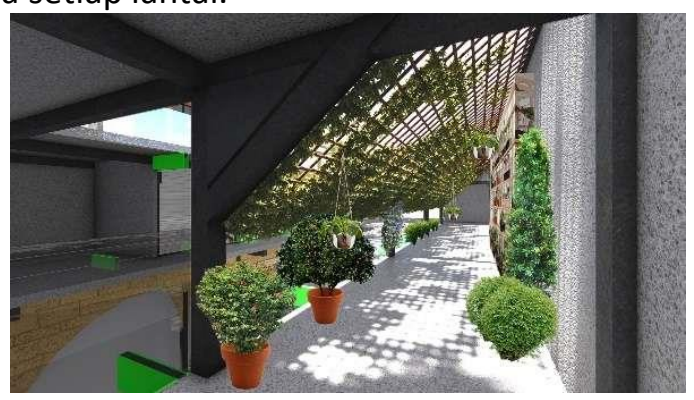

Gambar 12: Lt 3. Urban Plant Sumber:

Pada lantai 3 yaitu bagian urban plant ini dibuat agar masyarakat yang sudah mengenal tanaman pada taman di bangunan ini, berkontribusi untuk lebih mengenal alam dan lebih menjaga lingkungan, dan mereka dapat membeli berbagai jenis tanaman hias pada toko ini untuk dibawa pulang.

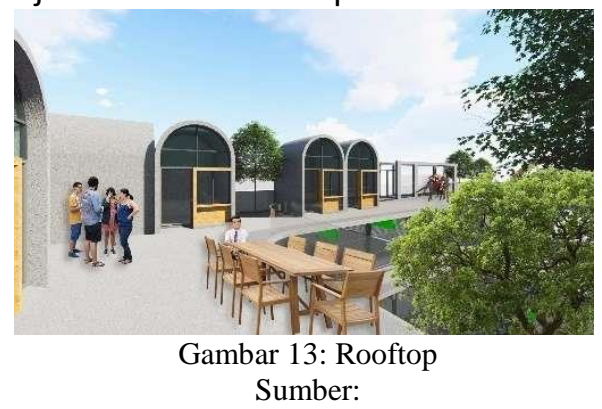

Pada bagian rooftop terdapat retail mikro dan taman, yang berfungsi sebagai tempat nongkrong pengunjung. 


\section{Tapak 2 (Jl. Kelinci 2, Sawah Besar, Jakarta Pusat.)}

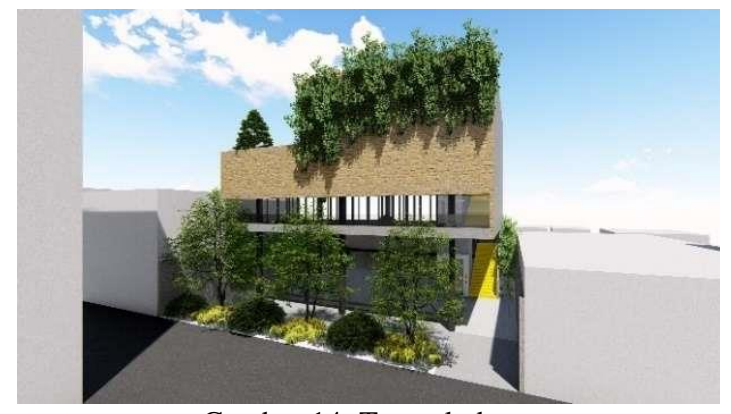

Gambar 14: Tampak depan Sumber:

Tapak ini dikembangkan untuk menampung kegiatan warga tempat tinggal sekitar, disamping tapak merupakan bangunan masjid yang biasanya mengadakan berbagai acara, namun karena tidak cukupnya luas bangunan untuk menampung undangan maka jalan di depan Masjid biasanya ditutup dan dijadikan tempat duduk, maka dari itu pada tapak ini dibuat ruang serbaguna pada lantai dasar untuk membantu menampung undangan serta dapat digunakan sebagai tempat berkumpul warga.

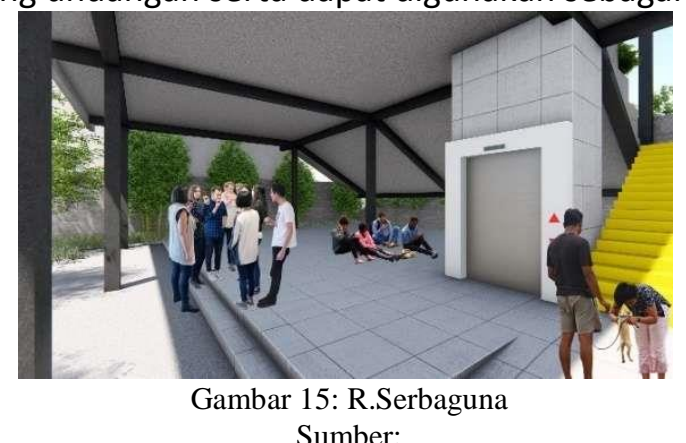

Pada lantai 2 dan lantai 3 dibuat perpustakaan digital, dimana anak-anak sampai dewasa dapat mencari informasi. Terdapat ruang luar perpustakaan yang berfungsi untuk memasukkan cahaya matahari Timur dan juga sebagai tempat duduk bersama.

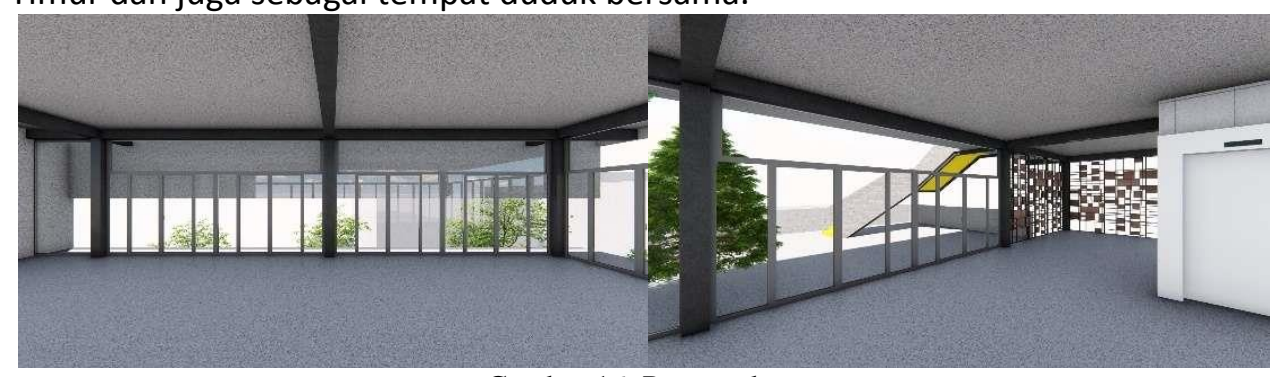

Gambar 16: Perpustakaan Sumber:

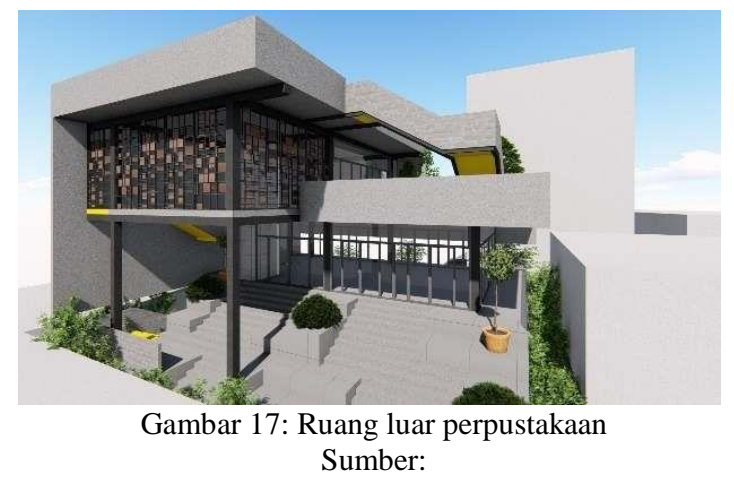

Pada lantai 3 dan paling atas merupakan rooftop garden yang berfungsi sebagai pengisi kegiatan untuk lansia dan anak kecil, untuk mengenal dan merawat tumbuhan bersama. 


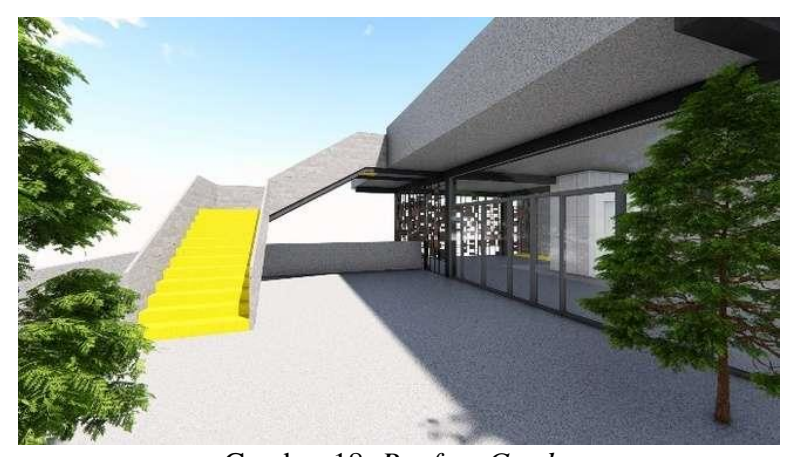

Gambar 18: Rooftop Garden

Sumber:

\section{Tapak 3 (Jl. Kelinci Raya, Sawah Besar, Jakarta Pusat)}

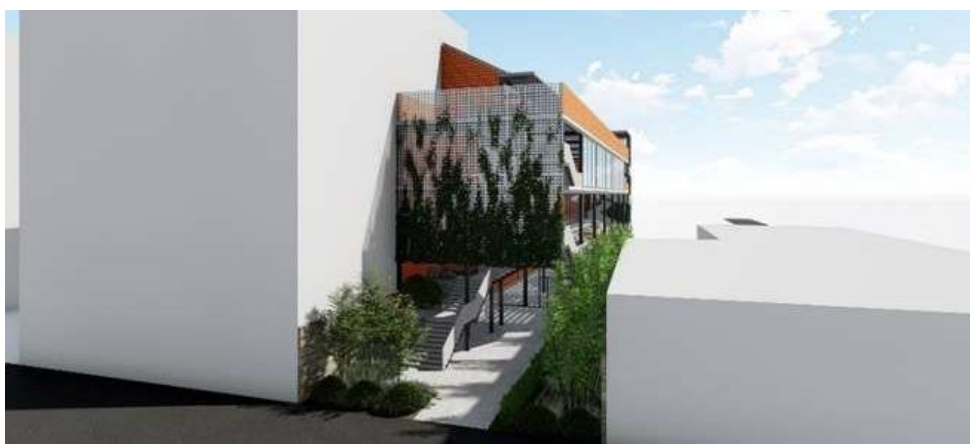

Gambar 19: Tampak Depan Sumber:

Tapak 3 memiliki program seperti : gym, working space, dan pub. Pada bagian tampak depan diberikan kisi-kisi yang ditumbuhi tanaman rambat guna menghalangi cahaya matahari Barat, sehingga panas tidak masuk ke area ruang kerja, namun pada bagian sisi Timur, diberikan bukaan dan jendela untuk memasukkan matahari Timur sebagai pencahayaan alami.

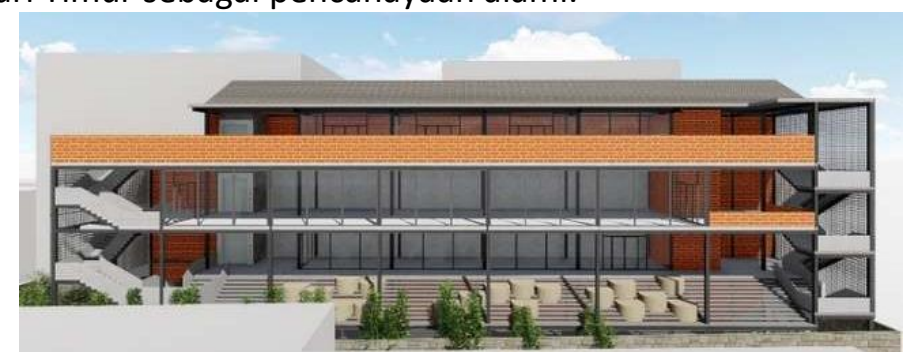

Gambar 20: Tampak Timur Sumber:

Pada bagian Timur tangga menjadi tempat masuknya pencahayaan alami beserta tempat meeting tidak formal atau tempat duduk bersama.

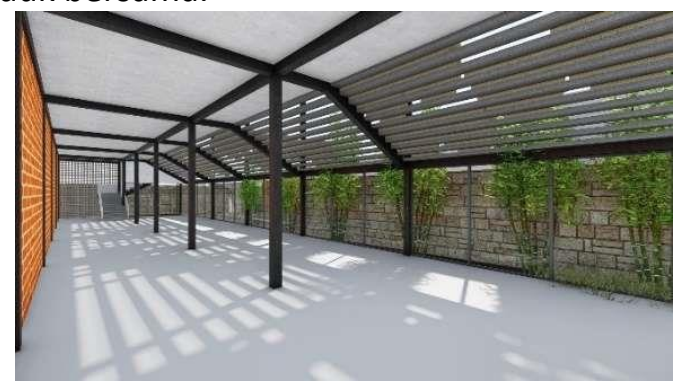

Gambar 21: Tampak Timur Sumber:

Pada ruang gym pencahayaan alami masuk dari sela sela anak tangga sehingga mengurangi panas, dan menghadap ke arah taman agar memberikan motivasi dan menyegarkan yang berolahraga. 


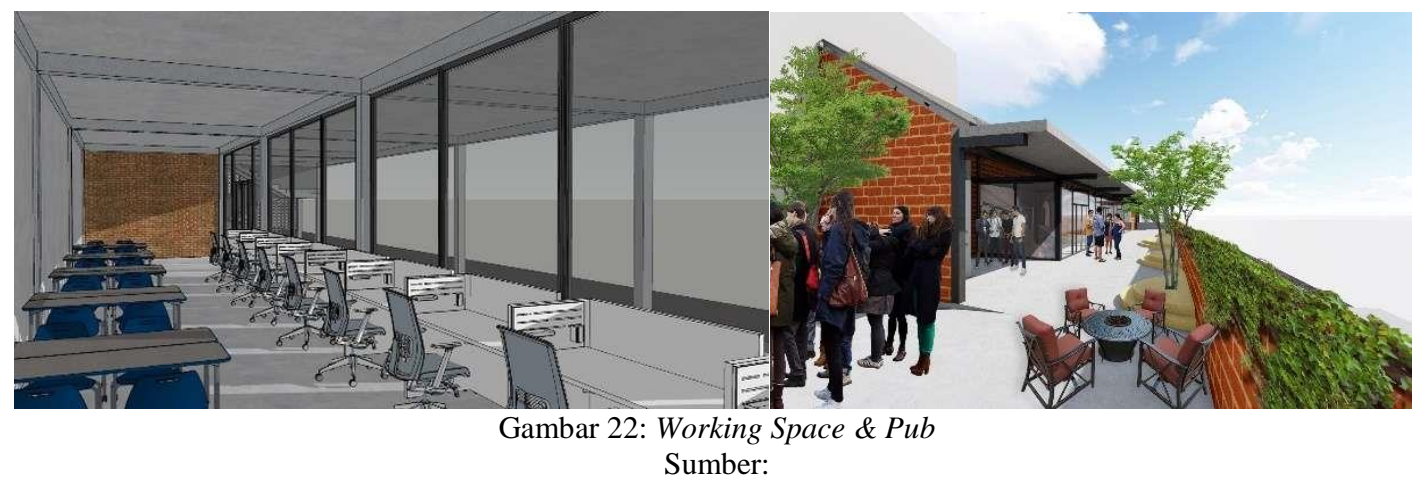

Pub sebagai tempat berbincang dan bersantai selepas bekerja seharian atau ketika sedang beristirahat, dilengkapi dengan panggung untuk live music.

\section{KESIMPULAN DAN SARAN}

\section{Kesimpulan}

Berdasarkan isu dan rumusan masalah mengenai stres yang dialami masyarakat perkotaan, solusi yang dihasilkan merupakan sampel penelitian pada 3 titik lokasi di Kelurahan Pasar Baru, yaitu titik pertama shop \& market area yang berfokus sebagai passage dari Jalan Pasar Baru 1 menuju Jalan Belakang Pasar Baru, dilengkapi dengan toko mikro bagi para startup karena lokasinya yang strategis serta tempat duduk sebagai tempat beristirahat para pengunjung di Pasar Baru, juga penambahan unsur alam dan permainan ketinggian ruang sebagai aktivator suasana hati pengunjung. Titik kedua sebagai living \& community area yang memenuhi kebutuhan ruang dan aktivitas pada daerah perumahan seperti pada lantai dasar digunakan sebagai ruang serbaguna agar masyarakat dapat melakukan kegiatan di masjid tanpa menutup jalan, maupun kegiatan lainnya secara bergantian, tempat ini diarahkan kepada anak - anak sampai remaja sebagai ruang membaca secara online maupun offline. Ruangan di dalam di desain agar pengunjung dapat merasakan cahaya alami dan memasukkan udara, serta dilengkapi dengan taman dan tempat menanam sebagai kegiatan tambahan bagi warga guna mengisi kegiatan positif yang berdampak baik bagi lingkungan. Titik ketiga work \& office area yang terletak di daerah perkantoran yang berfungsi sebagai tempat meeting, ruang kerja, bar, maupun tempat gym. Pembentukkan ruang ini dibuat karena potensi kebutuhan pekerja kantor maupun startup akan ruang kerja yang nyaman dan sesuai, agar dapat lebih fokus dalam bekerja.

\section{Saran}

Perlu dilengkapi kembali untuk pembahasan perkembangan menuju pembentukan sebuah ekologi baru, dimana bentuk dari perkembangan penelitian saat ini, yaitu sampel yang sudah siap disebarkan ke berbagai daerah dan membentuk sebuah jaringan baru yang dilengkapi dengan jaringan digital yang dapat membantu mengumpulkan informasi dan menyebarkan informasi sehingga kedepannya pembangunan fasilitas publik semakin sesuai dengan kebutuhan terkini para penggunanya. 


\section{REFERENSI}

Akhmad, MH. (23 Juli 2017) Kesehatan jiwa warga kota tergantung kondisi ruang publiknya. Retrieved from URL https://tirto.id/kesehatan-jiwa-warga-kota-tergantung-kondisi-ruang-publiknya-ctcy

Antonius, P. (10 Oktober 2019) Warga ibu kota rentan stress. Retrieved from URL https://www.kompas.id/baca/utama/2019/10/10/warga-ibu-kota-rentan-stres

Crystal Raypole (2019, September 30) How to Hack Your Hormones for a Better Mood. Retrieved from URL https://www.healthline.com/health/happy-hormone

Duke University. (2005, March 24). Emotional Memories Function In Self-Reinforcing Loop.ScienceDaily. Retrieved from URL www.sciencedaily.com/releases/2005/03/050323130625.htm

Hokuma Karimova, MA. (2021, Mei 20) The Emotion Wheel: What It Is and How to Use It. Retrieved from URL https://positivepsychology.com/emotion-wheel/

Lawrence EM, Rogers RG, Wadsworth T. (2015, September 18). Happiness and longevity in the United States. Retrieved from URL https://doi.org/10.1016/j.socscimed.2015.09.020

Oldenburg, R. (1999, August 18) The Great Good Place. Da Capo Press

Pekrun, R., \& Linnenbrink-Garcia, L. (2014). Introduction to emotions in education. In R. Pekrun \& L. Linnenbrink-Garcia (Eds.), International handbook of emotions in education (pp. 1-10). Routledge/Taylor \& Francis Group.

Wolkowitz OM, Epel ES, Reus VI, Mellon SH. (2010, April 01). Depression gets old fast: do stress and depression accelerate cell aging? Retrieved from URL https://doi.org/10.1002/da.20686

https://dictionary.apa.org/crowding 